ISSN 2413-0877 Volume 2 (2015) 495

The 3rd International Conference on Biological Science 2013

(The 3rd ICBS-2013)

\title{
EVALUATION OF THE POTENTIAL WEEDINESS AND BIOCHEMICAL PROPERTIES OF TRANSGENIC RICE WITH GLU-1DX5 GENE
}

\author{
Nono Carsono ${ }^{1}$, A. Quddus BM ${ }^{3}$, Diani Damayanti², Gigih IP³, \\ Murdaningsih $\mathrm{HK}^{1}$, and $\mathrm{M}$. Herman ${ }^{2}$ \\ ${ }^{1}$ Lab. of Plant Biotechnology \&Breeding, Faculty of Agriculture, UniversitasPadjadjaran, \\ Bandung Sumedang 45363. \\ 2 Indonesian Center for Biotechnology and Genetic Resources Research and Development (BB Biogen), Bogor. \\ ${ }^{3}$ Alumni, Lab. of Plant Biotechnology \&Breeding, Faculty of Agriculture, Universitas Padjadjaran, Bandung \\ Sumedang 45363. \\ e-mail : ncarsono@unpad.ac.id
}

\begin{abstract}
A Glu-1Dx5 allele, encoding for a high molecular weight glutenin sub unit Dx5, has been experimentally proven to be a major determinant for dough elasticity and functionality of bread wheat. Considering its important role, this gene has been successfully transferred to rice cv Fatmawati using particle bombardment. Some promising lines derived from consecutive generations have been obtained, however early biosafety assessment for transgenic plant is required in order to scientifically evaluate the equality of transgenic rice lines to their counterpart. Two promising lines $\left(\mathrm{T}_{3}-19\right.$ and $\left.\mathrm{T}_{3}-20\right)$ which are supposed to be homozygous were subjected to weediness and biochemical evaluation. The evaluation of invasiveness as a measure of weediness was carried out in biosafety containment of BB Biogen, Bogor by growing a mixture of transgenic and nontransgenic. Biochemical testing was evaluated for nitrogen, carbohydrate, protein, fat, vitamin, ash, minerals (Ca and $\mathrm{Mg}$ ), and 17 amino acids. Weediness testing revealed that competitiveness of transgenic rice plants grown in screen house as well as biosafety containment was equal with those of non transgenic plants, suggesting that transgenic rice plants have not high potency to be invasive. Transgenic rice seed had equal nutritive value with those of counterpart. These results indicate that transgenic rice plants (seeds) are substantially equivalent to non transgenic original lines except for the presence of Glu-1Dx5 gene.
\end{abstract}

Key words: Glutenin, Invasiveness, Nutrient composition, Transgenic rice.

ISSN 2413-0877 (C) 2015 The Authors.

Published by KnowledgeE Publishing Services This is an open access article under the CC BY-NC-ND license (http://creativecommons.org/licenses/by-nc-nd/4.0)

Selection and Peer-review under responsibility of the 3rd ICBS-2013

Doi http://dx.doi.org/10.18502/kls.v2i1.200 